\title{
Chronic Peripheral Ghrelin Injection Exerts Antifibrotic Effects by Increasing Growth Differentiation Factor 15 in Rat Hearts With Myocardial Fibrosis Induced by Isoproterenol
}

\author{
Qian REN ${ }^{1}$, Ping LIN ${ }^{1}$, Qin WANG ${ }^{1}$, Bin ZHANG ${ }^{1}$, Li FENG ${ }^{1}$ \\ ${ }^{1}$ Geriatric Department of the Third Hospital of Hangzhou, Hangzhou, China
}

Received April 10, 2019

Accepted October 29, 2019

Epub Ahead of Print December 19, 2019

\begin{abstract}
Summary
This study aimed to investigate the anti-fibrotic effects of ghrelin in isoproterenol (ISO)-induced myocardial fibrosis and the underlying mechanism. Sprague-Dawley rats were randomized to control, ISO, and ISO + ghrelin groups. ISO ( $2 \mathrm{mg} / \mathrm{kg}$ per day, subcutaneous) or vehicle was administered once daily for 7 days, then ghrelin $(100 \mu \mathrm{g} / \mathrm{kg}$ per day, subcutaneous) was administered once daily for the next 3 weeks. Ghrelin treatment greatly improved the cardiac function of ISO-treated rats. Ghrelin also decreased plasma brain natriuretic peptide level and ratios of heart weight to body weight and left ventricular weight to body weight. Ghrelin significantly reduced myocardial collagen area and hydroxyproline content, accompanied by decreased mRNA levels of collagen type I and III. Furthermore, ghrelin increased plasma level of growth differentiation factor 15 (GDF15) and GDF15 mRNA and protein levels in heart tissues, which were significantly decreased with ISO alone. The phosphorylation of Akt at Ser473 and GSK-3 $\beta$ at Ser9 was decreased with ISO, and ghrelin significantly reversed the downregulation of $p$-Akt and $p$-GSK-3 $\beta$. Mediated by GDF15, ghrelin could attenuate ISO-induced myocardial fibrosis via Akt-GSK-3 $\beta$ signaling.
\end{abstract}

\section{Key words}

Ghrelin • Myocardial fibrosis • Growth differentiation factor $15 \bullet$ Akt/GSK-3ß pathway

\section{Corresponding author}

P. Lin, Geriatric Department of the Third Hospital of Hangzhou, Hangzhou, 310009, China. E-mail: linp916@yahoo.com

\section{Introduction}

Despite significant advances in therapy, heart failure (HF), known as the ultimate outcome in cardiovascular diseases including hypertension, myocardial infarction and valvular dysfunction, remains a major clinical problem of high morbidity and mortality worldwide (Shan and Mann 2011). Myocardial fibrosis is characterized by uncontrolled proliferation of fibroblasts and excessive deposition of extracellular matrix proteins in myocardium, in response to pathological stimuli, such as myocardial injury. Myocardial fibrosis is considered an important pathological mechanism in the progression of HF and contributes to myocardial stiffness, cardiac dysfunction, arrhythmias and sudden death (Gonzalez et al. 2018). Therefore, inhibiting myocardial fibrosis is an effective way to prevent HF (Travers et al. 2017). However current anti-fibrotic therapy is limited, and novel mediators of myocardial fibrosis need to be identified for the development of better therapeutics.

Growth factors and chemokines, including insulin-like growth factor, fibroblast growth factor, and transforming growth factor (TGF), are some of the beststudied mediators and have important roles in proliferation, extracellular matrix deposition and organ fibrosis by interacting with corresponding receptors (Lewis et al. 2018). Several recent studies have demonstrated that growth differentiation factor 15 (GDF15), belonging to the superfamily TGF $\beta$, plays a crucial role in the progression of HF (Wollert and Kempf 2012). As a stress-responsive cytokine, GDF15 is weakly produced in the heart under normal physiological 
conditions, but its level increases rapidly in response to cardiovascular injury, such as pressure overload, HF, and ischemia/reperfusion. Increased circulating GDF15 levels were found associated with severity of chronic HF as reflected by New York Heart Association class, peripheral edema, and increased level of brain natriuretic peptide (BNP) (Anand et al. 2010). In addition, elevated GDF15 plasma level is a surrogate marker of risk of mortality in HF (Kempf and Wollert 2009). However, the responses observed in animal studies are contrary to what is found in humans. In animal studies, GDF15 has protective effects by inhibiting apoptosis, hypertrophy, and adverse remodeling in the injured heart (Heger et al. 2010, $\mathrm{Xu}$ et al. 2014). Thus, further research is essential before considering GDF15 as a therapeutic target in cardiovascular diseases, especially for myocardial fibrosis.

Ghrelin is a 28-amino acid orexigenic peptide released primarily from oxyntic glands of the gastric mucosa. It is an endogenous ligand of the growth hormone secretagogue receptor type 1a (GHS-R1a), which stimulates growth hormone secretion and is well known for its regulation of metabolism and appetite. Ghrelin and its receptor are both expressed throughout the heart and vasculature and play an important role in the cardiovascular system of rodents and healthy humans (Lilieness and Frishman 2016). Several lines of evidence indicated that ghrelin has robust cardioprotective effects including enhancing endothelial and vascular function, inhibiting sympathetic drive, preventing atherosclerosis, and decreasing blood pressure (Shirai et al. 2015, Virdis et al. 2015, Wang et al. 2017, Camargo-Silva et al. 2018). Also, in a rat model of HF, ghrelin attenuated ventricular remodeling and improved cardiac function (Eid et al. 2018, Mao et al. 2015). Ghrelin was found to reduce myocardial fibrosis in rats with myocardial infarction and angiotensin II-induced cardiac fibroblasts by inhibiting NADPH oxidase-reactive oxygen species signaling (Wang et al. 2018). In addition, ghrelin could have a protective role by regulating the content of growth factors (Cieszkowski et al. 2017, Wang et al. 2015). However, whether the anti-fibrotic effects of ghrelin are mediated by GDF15 has not been fully elucidated.

Here we aimed to investigate the anti-fibrotic effects of ghrelin in isoproterenol (ISO)-induced myocardial fibrosis in rats. Furthermore, we explored whether ghrelin exerted its anti-fibrotic effect via GDF15.

\section{Methods}

\section{Animals and experimental protocol}

Male Sprague-Dawley rats (180-200 g) were purchased from Vital River Laboratories (Beijing). The rats were maintained at $22-25^{\circ} \mathrm{C}$ under a $12-\mathrm{h}$ light/dark cycle with relative humidity $60 \%$ and unrestricted access to food and water for a 1-week acclimatization period. All animal experimental procedures were performed according to the Guide for the Care and Use of Laboratory Animals of the US National Institutes of Health.

After acclimatization, rats were randomly divided into three groups $(n=6)$ for treatment: control, ISO, ISO + ghrelin. ISO ( $2 \mathrm{mg} / \mathrm{kg}$ per day, subcutaneous) or vehicle was administered once daily for 7 days to induce the rat model of myocardial fibrosis as described (Lai et al. 2016). Then ghrelin $(100 \mu \mathrm{g} / \mathrm{kg}$ per day, subcutaneous) was administered once daily for the next 3 weeks (Eid et al. 2018). The control and ISO groups were administered the equivalent volume of saline at the same times.

\section{Hemodynamic assessment of cardiac physiology}

At the end of the experiment, the rats were intraperitoneally anesthetized with urethane $(1 \mathrm{~g} / \mathrm{kg})$, and a catheter filled with heparin saline $(500 \mathrm{U} / \mathrm{ml})$ was inserted into the left ventricle from the right carotid artery to record hemodynamic parameters, including left ventricular systolic pressure (LVSP), left ventricular enddiastolic pressure (LVEDP), heart rate (HR), maximum contraction velocity $\left(+\mathrm{dp} / \mathrm{dt}_{\max }\right)$, and maximum relaxation velocity (-dp/dt $\mathrm{dmax}$ ) by using a PowerLab data-acquisition system (AD Instruments, Sydney, Australia).

After hemodynamic parameters were measured, hearts were excised and heart weight and left ventricle weight were determined. Ratios of heart weight to body weight and left ventricular weight to body weight were calculated by dividing heart weight and left ventricular weight by body weight as an indicator of cardiac remodeling. Then, heart tissues were quickly frozen in liquid nitrogen and stored at $-80^{\circ} \mathrm{C}$. The plasma was prepared by centrifuging blood samples at $3000 \mathrm{rpm}$ for $15 \mathrm{~min}$ and was frozen at $-80^{\circ} \mathrm{C}$.

\section{Masson trichrome staining}

After fixation for $24 \mathrm{~h}$ in $4 \%$ paraformaldehyde, heart blocks were dehydrated, embedded in paraffin, and cut into $4-\mu \mathrm{m}$-thick slices. Slices were heated overnight at 
$37^{\circ} \mathrm{C}$, dewaxed, and stained with Masson trichrome by standard procedures. The heart sections were visualized under a light microscope (Olympus, Tokyo, Japan). Images were obtained in five random fields per section and were quantified by using ImageJ. Area of fibrosis was divided by total area of microscopic fields.

\section{Determination of myocardial hydroxyproline content}

Myocardial hydroxyproline content was measured by using a hydroxyproline detection kit (Nanjing Jiancheng Biotechnique Institute, Nanjing, China) according to the manufacturer's instructions and normalized to total protein.

\section{Measurement of plasma BNP and GDF15}

Plasma levels of the BNP and GDF15 were measured by using ELISA kits (R\&D Systems, USA) according to the manufacturer's instructions.

\section{Western blot analysis}

Protein extracted from heart tissue was quantified by using BCA reagent, and protein samples were denatured at $99{ }^{\circ} \mathrm{C}$ for $5 \mathrm{~min}$. An amount of $50 \mu \mathrm{g}$ protein was fractionated on $10 \%$ SDS-PAGE gels, then transferred to polyvinylidene fluoride membranes, which were blocked with $5 \%$ nonfat milk for $1 \mathrm{~h}$, then incubated with the primary antibodies antiphospho(Ser473)-Akt ( $p$-Akt), anti-Akt, antiphospho(Ser9)-GSK-3 $\beta$ ( $p$-GSK-3 $\beta$ ), anti-GSK-3 $\beta$ and anti-GDF15 (1:1000, Cell Signaling Technology, country), with GAPDH as an internal control (1:2000, Poteintech, country) at $4{ }^{\circ} \mathrm{C}$ overnight. After washing with TBST three times, membranes were incubated with horseradish peroxidase-conjugated secondary antibodies at room temperature for $1 \mathrm{~h}$. Target bands were detected with SuperSignal West Pico Chemiluminescent Substrate (Thermo Scientific-Pierce, USA). The band intensity was quantified by using ImageJ.

\section{Real-time $q P C R$}

Frozen heart tissues were suspended in Trizol reagent (Invitrogen, Carlsbad, USA), and total RNA was extracted according to the manufacturer's instructions. Reverse transcription involved using a Reverse Transcription Kit (Toyobo, Osaka, Japan). A SYBRGreen RT-PCR Kit from Toyobo was used for quantitative real-time qPCR analysis with the StepOnePLUS Real-time PCR system (Applied Biosystems, Foster, USA), according to the manufac- turer's instructions. Gene-specific primers were used to detect

Rat GDF15:

Forward: 5'-GACCTAGGTTGGAGCGACTG-3'; reverse: 5'-TAAGAACCACCGGGGTGTAG-3';

Collagen I:

forward: 5'-TATGCTTGATCTGTATGTGCCACAAT-3'; reverse: 5'-TCGCCCTCCCGTTTTTG-3';

Collagen III:

forward: 5'-CAGCTGGCCTTCCTCAGACT-3'; reverse: 5'-TGCTGTTTTTGCACTGGTATG-TAA-3'

The samples were normalized against endogenous rat $\beta$-actin (forward: 5'-TACCACATCCAAGGAAGGCAGCA-3'; reverse: 5'-TGGAATTACCGCGGCTGCTGGCA-3'), and fold changes were calculated by using the formula $2^{-\Delta \Delta \mathrm{Ct}}$.

\section{Statistical analyses}

Data are expressed as mean \pm SEM. Statistical analysis involved using SPSS v17.0 (SPSS, Inc., USA). Data for three groups were compared by two-way ANOVA. Data for two groups were compared by Students $t$-test. $p<0.05$ was considered statistically significant.

\section{Results}

Ghrelin improved cardiac function in rats with ISO-induced myocardial fibrosis

After 4 weeks of treatment, LVSP and $\pm d p / \mathrm{dt}_{\max }$ were decreased and LVEDP was increased with ISO versus control treatment. However, ghrelin treatment increased LVSP and $\pm \mathrm{dp} / \mathrm{dt}_{\max }$ but decreased LVEDP as compared with ISO alone (Fig. 1A-D). HR did not differ among the three groups (Fig. 1E). Thus, ghrelin treatment ameliorated ISO-induced cardiac dysfunction.

Ghrelin attenuated cardiac remodeling in rats with ISOinduced myocardial fibrosis

After 4 weeks of treatment, ratios of heart to body weight and left ventricle to body weight were increased with ISO (Fig. 2A-2B). However, ghrelin treatment reduced the ratios. In addition, plasma level of $\mathrm{BNP}$, an important biomarker of HF, was elevated after ISO treatment but was significantly attenuated with ISO + ghrelin (Fig. 2C). Thus, ISO-induced left ventricular remodeling was significantly reduced by ghrelin. 
Ghrelin alleviated cardiac fibrosis in rats with ISO-induced myocardial fibrosis

Masson's trichrome staining showed fibroblast aggregation and increased interstitial collagen volume in the ISO group versus controls, and this fibrotic response was attenuated by ghrelin treatment (Fig. 3A-B). In addition, content of hydroxyproline (an indicator of fibrosis) was higher with ISO than control treatment and was partially decreased by ghrelin treatment (Fig. 3C). The mRNA levels of collagen I and III were higher with ISO than control treatment and were significantly decreased with ghrelin treatment (Fig. 3D-E). Therefore, ghrelin could inhibit the formation of myocardial fibrosis.
Ghrelin increased the generation of GDF15 and activated the Akt-GSK-3 $\beta$ pathway

Plasma GDF15 level and GDF15 mRNA and protein levels in heart tissue were significantly lower with ISO than control treatment, and ghrelin treatment could increase the generation of GDF15 (Fig. 4A-D).

To further explore the potential molecular mechanisms of the cardioprotective effects of ghrelin, we examined $p$-Akt and $p$-GSK-3 $\beta$ levels in heart tissue (Fig. 4E-F). As compared with control treatment, ISO treatment decreased the level of $p$-GSK-3 $\beta$ at Ser9 and decreased that of $p$-Akt at Ser473. However, ghrelin treatment significantly reversed the downregulation of $p$-Akt and $p$-GSK-3 $\beta$ in heart tissue.

B

A

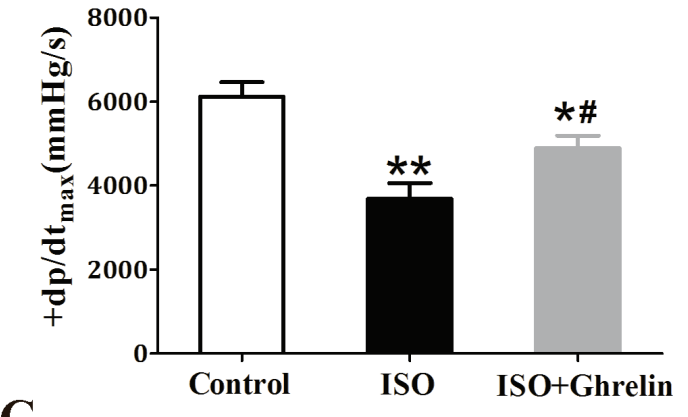

C

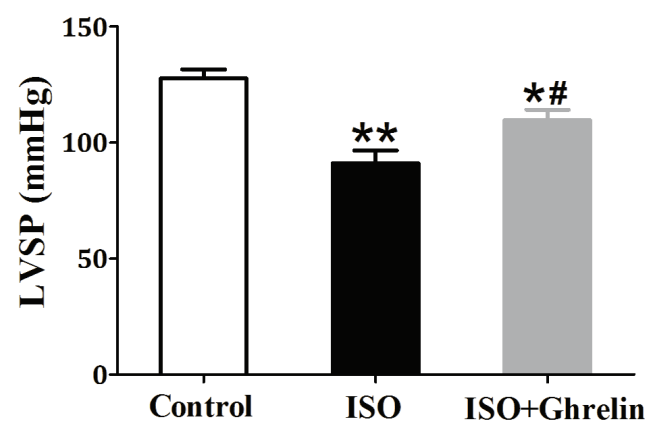

D
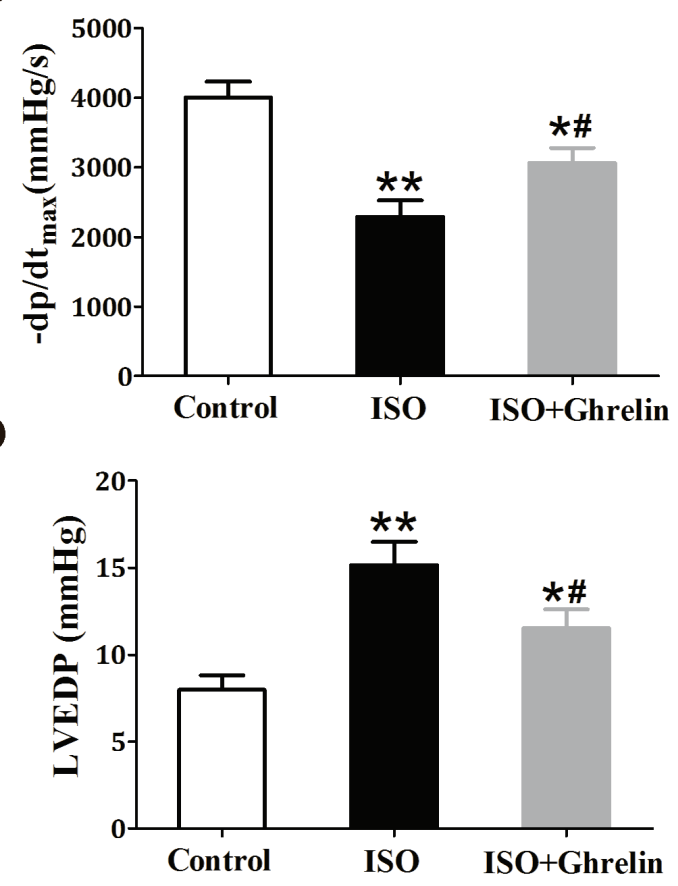

$\mathbf{E}$

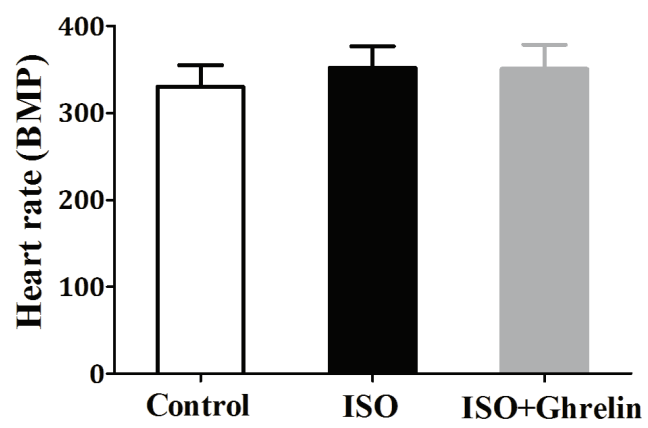

Fig. 1. Ghrelin improved cardiac function in isoproterenol-induced myocardial fibrosis rats. Rats were divided into 3 groups: control (saline $2 \mathrm{mg} / \mathrm{kg}$ per day, subcutaneous), ISO ( $2 \mathrm{mg} / \mathrm{kg}$ per day, subcutaneous), ISO + ghrelin. ISO or saline was administered for 7 days. Then ghrelin $(100 \mu \mathrm{g} / \mathrm{kg}$ per day, subcutaneous) was administered once daily for the next 3 weeks. Changes in (A) maximum contraction velocity $\left(+\mathrm{dp} / \mathrm{dt}_{\max }\right),\left(\right.$ B) maximum relaxation velocity $\left(-\mathrm{dp} / \mathrm{dt}_{\max }\right)$, (C) left ventricular systolic pressure (LVSP), (D) left ventricular end-diastolic pressure (LVEDP), and (E) heart rate (HR). Data are mean \pm SEM. ${ }^{*} p<0.05,{ }^{* *} p<0.01$ vs. Control; ${ }^{*} p<0.05$ vs. ISO. 
A

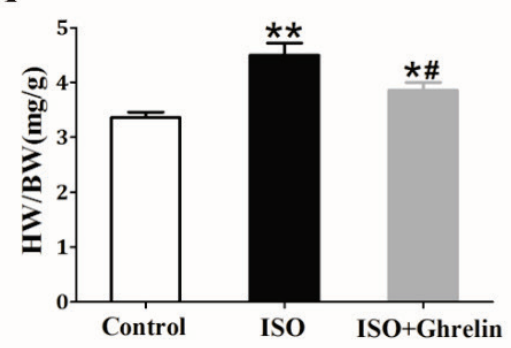

B

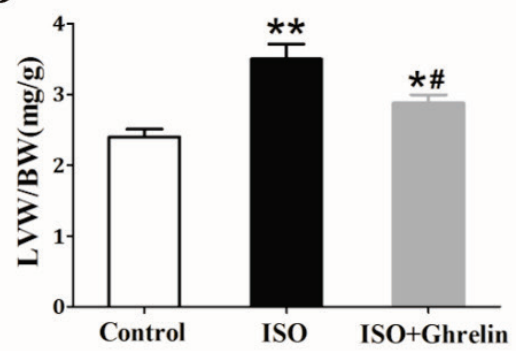

C

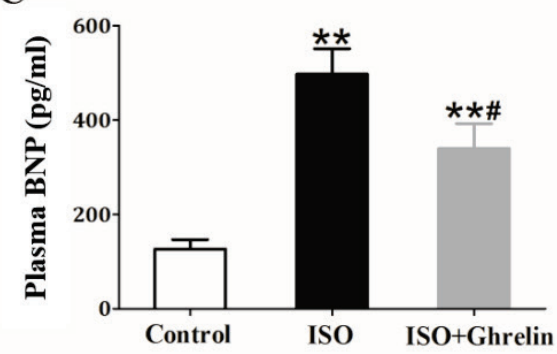

Fig. 2. Ghrelin attenuated cardiac remodeling in isoproterenol-induced myocardial fibrosis rats. (A) Heart to body weight ratio (HW/BW). (B) Left ventricular to body weight ratio (LVW/BW). (C) Brain natriuretic peptide (BNP) level in the plasma. Data are mean \pm SEM. ${ }^{*} p<0.05,{ }^{* *} p<0.01$ vs. Control; ${ }^{*} p<0.05$ vs. ISO.

A

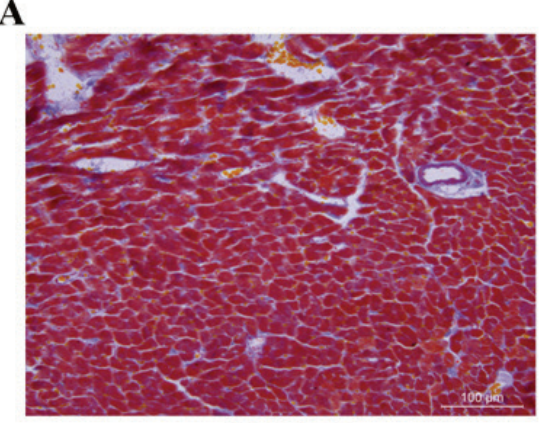

Control

B

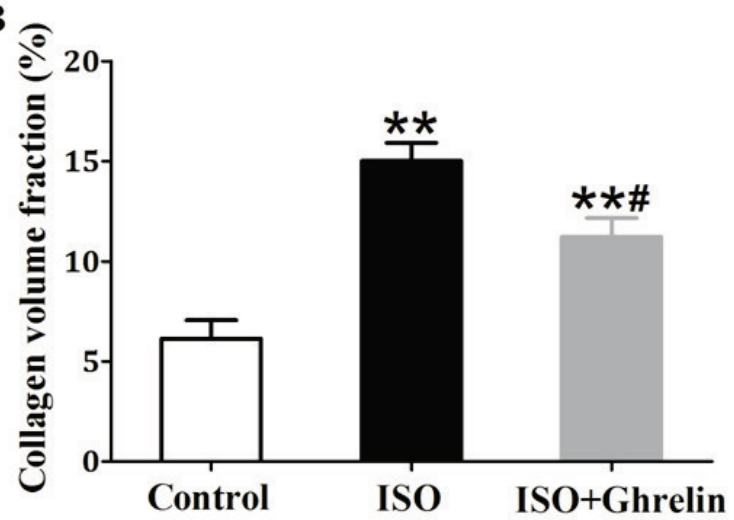

D

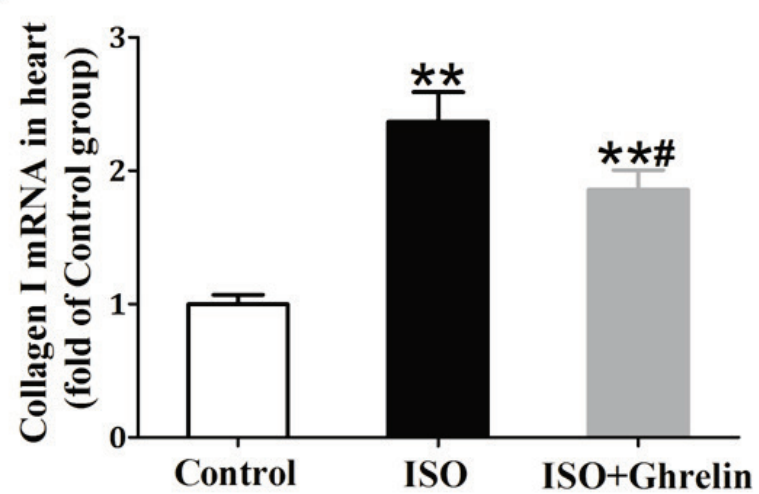

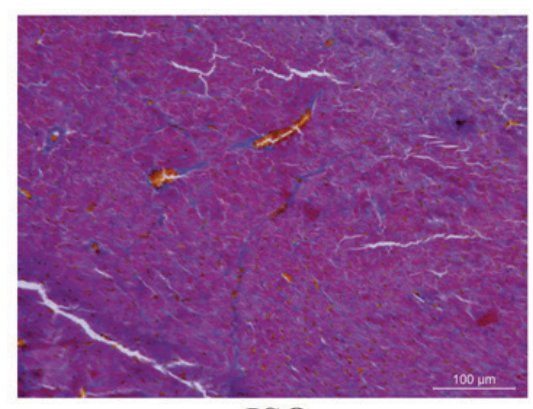

ISO

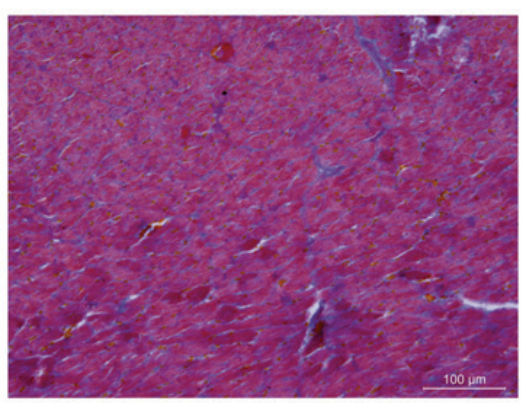

ISO+Ghrelin

C

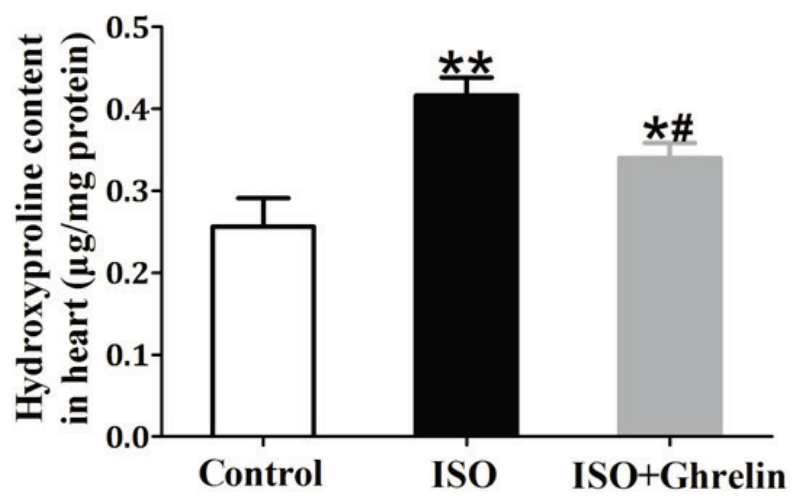

$\mathbf{E}$

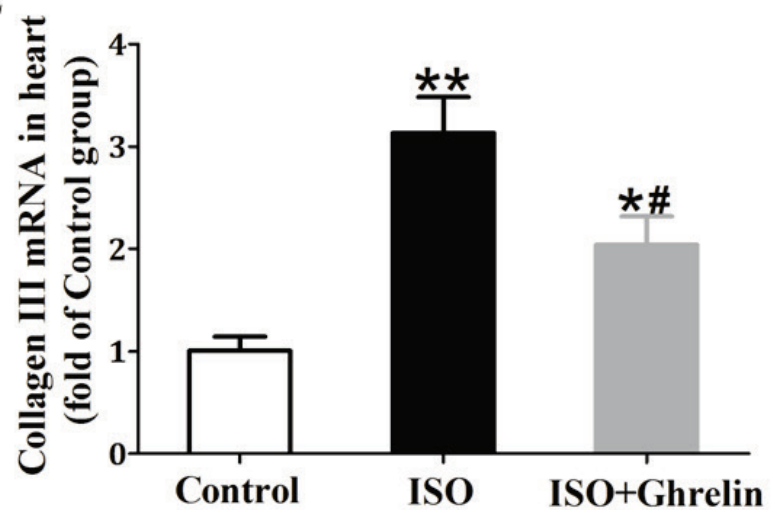

Fig. 3. Ghrelin alleviated cardiac fibrosis in isoproterenol-induced myocardial fibrosis rats: (A) Representative Masson's trichromestained left ventricular sections (scale bar $=100 \mu \mathrm{m}$ ). (B) Quantitative analysis for collagen volume fraction (\%) in heart tissue. (C) Hydroxyproline content in heart tissue. (D-E) Real-time PCR analysis of collagen I and III mRNA levels in heart tissue. Data are mean \pm SEM. ${ }^{*} p<0.05,{ }^{* *} p<0.01$ vs. Control; ${ }^{*} p<0.05$ vs. ISO. 
A

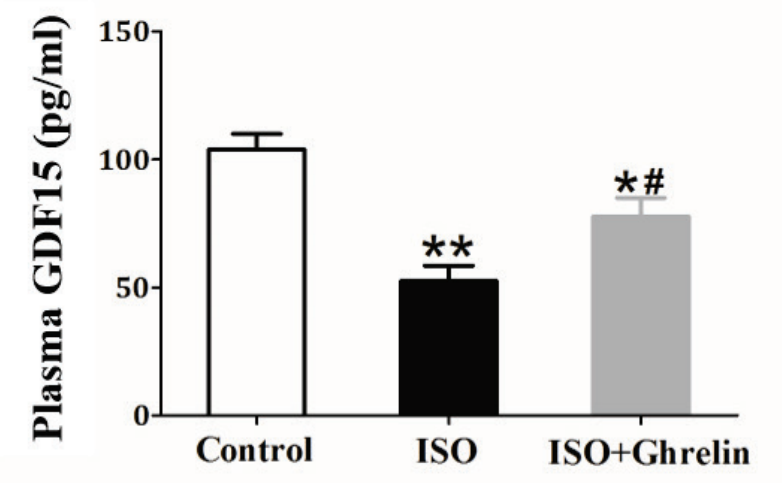

C
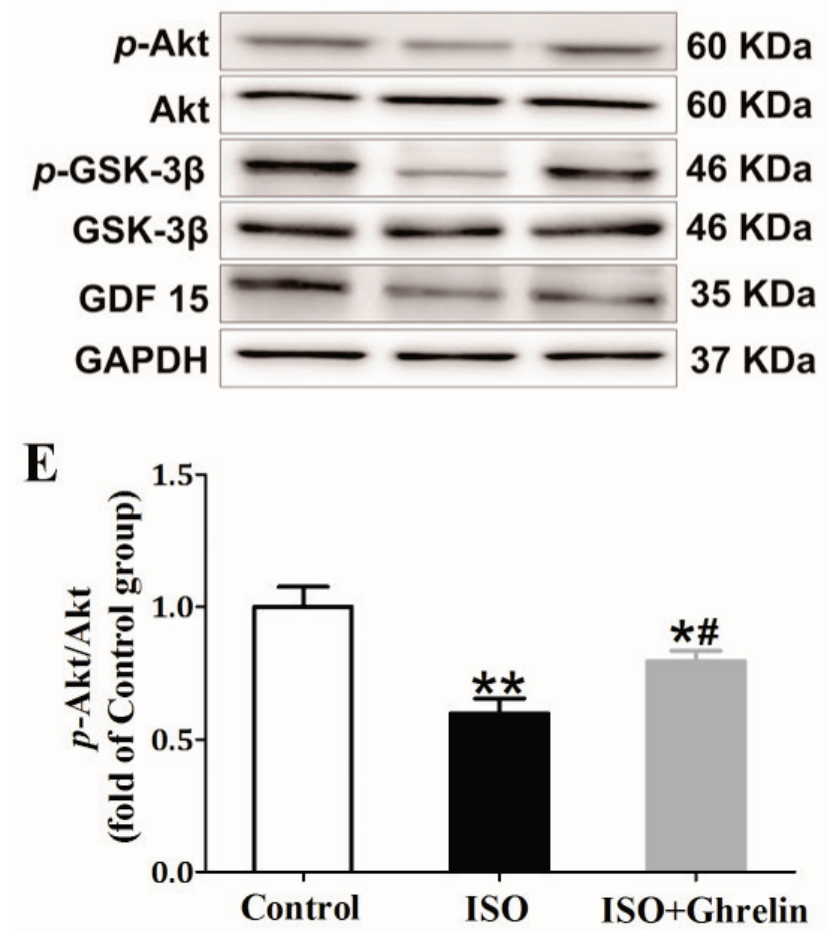

B
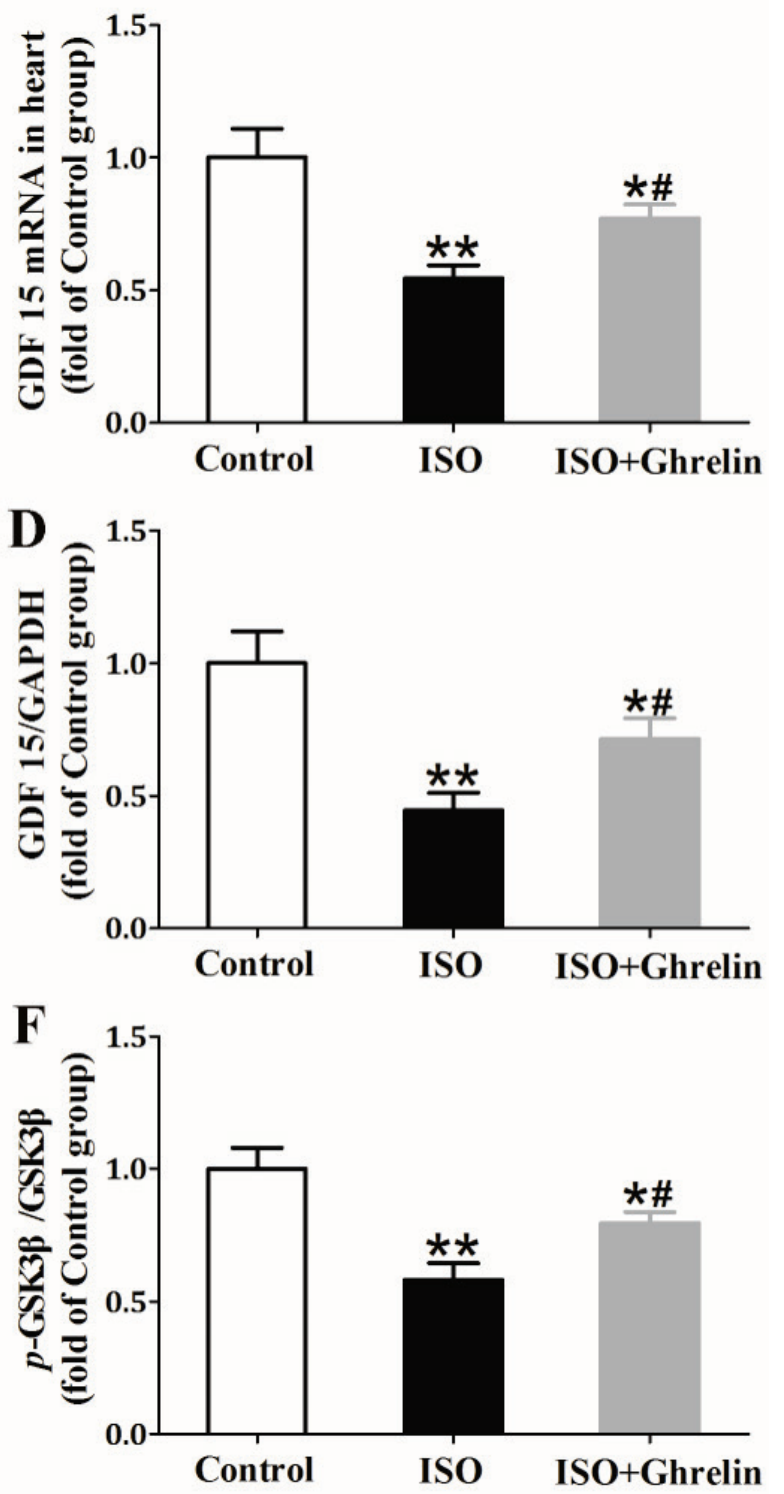

Fig. 4. Ghrelin increased the generation of growth differentiation factor 15 (GDF15) and activated Akt/GSK-3 $\beta$ pathway: (A) GDF15 level in plasma. (B) Real-time PCR analysis of GDF15 mRNA level in heart tissue. (C-F) Western blot analysis and quantification of

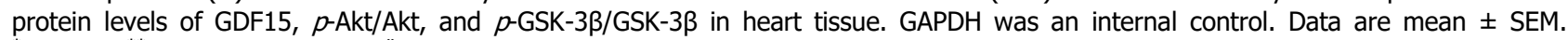
${ }^{*} p<0.05,{ }^{* *} p<0.01$ vs. Control; ${ }^{\#} p<0.05$ vs. ISO.

\section{Discussion}

This study aimed to investigate the anti-fibrotic effects of ghrelin in ISO-induced myocardial fibrosis and the underlying mechanism. Ghrelin improved cardiac function and reduced myocardial fibrosis in rats with ISO-induced myocardial fibrosis and significantly increased the production of GDF15, which plays an important role in the pathogenesis of myocardial fibrosis. Treatment with ghrelin might prevent myocardial fibrosis and improve outcomes.

Myocardial fibrosis is one of the major pathological changes in failing hearts and results in increased risk of morbidity and mortality worldwide. Common mediators of myocardial fibrosis include the renin-angiotensin system, TGF- $\beta$ and tumor necrosis factor $\alpha$ (Prabbu and Frangogiannis 2016, Zhang et al. 2011). The excessive activation of the sympathetic nervous system with increased plasma catecholamine level plays a critical role in the process of myocardial fibrosis. Sustained activation of $\beta$-adrenergic receptors leads to pathological myocardial fibrosis (Nuamnaichati et al. 2018). As well, transgenic mice with cardiac overexpression of $\beta$-adrenergic receptors showed myocardial fibrosis (Peter et al. 2007).

The nonselective $\beta$-adrenergic receptor agonist, 
ISO, has been widely used to induce a non-invasive reliable model of myocardial fibrosis (Shih et al. 2018, Vergaro et al. 2016). In the present study, rats were subcutaneously injected with $2 \mathrm{mg} / \mathrm{kg}$ ISO once daily for 7 days to establish the myocardial fibrosis model. Subcutaneous administration of ISO produced patchy myocardial necrosis with subsequent hypertrophy, fibrosis, and remodeling leading to HF. After 4-week treatment, we measured hemodynamic parameters such as LVSP, $\pm \mathrm{dp} / \mathrm{dt}_{\max }$ and LVEDP to assess cardiac function. LVSP and $\pm \mathrm{dp} / \mathrm{dt}_{\max }$ were significantly decreased and LVEDP was increased, which indicates cardiac dysfunction in the ISO-treated rats. In addition, plasma BNP level and ratios of heart to body weight and left ventricle to body weight were increased, indicating cardiac remodeling in ISO-treated rats. After myocardial injury, cardiac fibroblasts proliferate, differentiate into myofibroblasts and produce excessive extracellular matrix to fill in the gaps created by the removal of dead cells, because cardiomyocytes are nonrenewable. Diffuse interstitial fibrosis, a key morphological change that occurs as part of the structural myocardial remodeling that takes place after myocardial injury disturbs the collagen fiber network of the myocardium. Sections stained with Masson's trichrome in the left ventricle of our rats showed wide areas of excessive collagen deposition between cardiac muscle fibers after ISO treatment. This observation was confirmed statistically by a significant increase in the percentage area of fibrosis and content of hydroxyproline, an indicator of fibrosis. Consistently, collagen I and III mRNA levels were greatly increased after ISO treatment, which indicated cardiac fibroblast activation and excessive extracellular matrix deposition. All these findings indicated successful establishment of the rat model of ISO-induced myocardial fibrosis, which parallels the results of previous studies (Mohamed et al. 2015, Yin et al. 2015).

Next, we investigated the anti-fibrotic effect effects of ghrelin. Ghrelin is a growth hormone (GH)-releasing polypeptide that was first isolated from the rat stomach in 1999. Since then, ghrelin has been found to have a plethora of physiological effects that go far beyond its initial characterization as a GH secretagogue. In the cardiovascular system, ghrelin has largely cardiac beneficial effects, including protection against ischemia/reperfusion injury, attenuation of left ventricular remodeling after myocardial infarction, and improvement of left ventricular function (Virdis et al. 2016).
Exogenous administration of ghrelin improved the cardiac function and prognosis of patients with end-stage HF (Nagaya et al. 2004). In addition, ghrelin suppressed the myocardial fibrosis of rats with post-myocardial infarction cardiac failure by adjusting the activating A-follistatin imbalance (Yang et al. 2018). However, the role of ghrelin in ISO-induced myocardial fibrosis and the relevant regulatory mechanism have not been well studied.

Interestingly, Camargo-Silva et al. (2018) reported that ghrelin potentiated cardiac reactivity to stress by modulating sympathetic control and betaadrenergic response. However, the suppression of ghrelin on sympathetic hyperexcitation in acute heart failure in rats was also reported in another article (Shirai et al. 2015). These differences may be attributed to i) the timeframe, and therefore, acute effects would be potentiation of cardiac function whereas the chronic actions would result in attenuation; ii) ghrelin effects on healthy hearts differ from those sampled during hypertension, cardiac hypertrophy and failure. In fact, literature reports ghrelin acts at the nucleus of the solitary tract to suppress sympathetic activity and to decrease arterial pressure (Lin et al. 2004). In rodents with myocardial infarction, ghrelin treatment reduces the increased plasma concentration of norepinephrine, and inhibits activated cardiac sympathetic nervous activity showed by the ratio of low-frequency to high-frequency power in a heart rate variability analysis (Soeki et al. 2008).

In our study, ghrelin treatment improved cardiac function, as certified by the increase of LVSP and $\pm \mathrm{dp} / \mathrm{dt}_{\max }$ and decrease of LVEDP. Ghrelin treatment also reduced plasma BNP level and ratios of heart to body weight and left ventricle to body weight. In addition, ghrelin significantly reduced the percentage area of fibrosis and hydroxyproline content, accompanied by a decrease of collagen type I and III mRNA levels. These results were consistent with Pei et al. (2014), who reported that ghrelin prevented doxorubicin-induced myocardial fibrosis and apoptosis via a GHSRindependent pathway. Also, chronic administration of hexarelin, a synthetic small peptide ghrelin analogue, attenuated myocardial fibrosis in spontaneously hypertensive rats (Xu et al. 2012). Therefore, ghrelin may be an effective treatment for myocardial fibrosis if the anti-fibrosis mechanism of ghrelin is well studied.

Growth factors and cytokines produced and secreted from cardiac myocytes and cardiac fibroblasts 
play an important role in regulating myocardial fibrosis. Among the factors that contribute to myocardial fibrosis, members of the TGF family are the best characterized and appear to be the key factors in driving myocardial fibrosis. The activation of TGF- $\beta$ promotes myofibroblast differentiation and transformation, enhances the extracellular matrix and inhibits the expression of matrix metalloproteinases by binding to a complex of type II-R and type I-R, then activating Smad pathways ( $\mathrm{Su}$ et al. 2017, Verjans et al. 2018). Meanwhile, the counterregulatory pathways that regulate TGF- $\beta 1$ activity are activated during the progression of myocardial fibrosis. For instance, bone morphogenetic proteins (BMPs), members of the TGF- $\beta$ family of cytokines, attenuate adverse fibrosis progression by suppressing TGF- $\beta 1$ via the downstream effector Smad proteins (Wang et al. 2012, Morine et al. 2018). Ghrelin also attenuates liver or renal fibrosis by inhibiting the TGF- $\beta 1 /$ Smad3 pathway (Sun et al. 2015, Mao et al. 2015). As a TGF-B/BMP superfamily member, GDF15 has been described as a promising cardioprotective agent, which is attributed to its anti-apoptotic, anti-inflammatory, or anti-hypertrophic effects demonstrated in animal models (Kempf et al. 2011, Kempf et al. 2006). GDF-15 may be acted as the compensatory mechanism in the pathological process of myocardial hypertrophy. Expression of GDF-15 is very low in healthy heart, while its expression significantly up-regulated in cardiac remodeling. As negative feedback mechanism, the up-regulation of GDF-15 blocks cardiac hypertrophy by inhibition of epidermal growth factor receptor transactivation (Xu et al. 2014). However, clinical studies in humans indicate an association of increased levels of GDF15 with increased all-cause mortality in HF patients (Santhanakrishan et al. 2012). So, whether the anti-fibrotic effects of ghrelin are mediated by GDF 15 need to be fully investigated.

In the present study, plasma GDF15 level and GDF15 mRNA or protein levels in rat heart tissue were significantly lower with ISO than control treatment, and ghrelin treatment could increase the level of GDF15. Our results indicate decreased production of GDF15 under the pathological state of myocardial fibrosis in rats, and ghrelin treatment increased the production of GDF15 to exhibit its anti-fibrotic effects. These results are consistent with Lok et al. (2012), who reported very low cardiac mRNA and protein levels of GDF-15 in myocardial fibrosis patients with non-ischemic dilated cardiomyopathy.
The Akt-GSK-3 $\beta$ pathway plays a critical role in the pathological fibrotic response. Akt activation inhibits cardiomyocyte apoptosis and improves the survival of cardiomyocytes. Akt exerts its protective effect by directly phosphorylating and inactivating GSK-3 $\beta$, which regulates the general protein translational machinery. Blood glucose variability can aggravate heart tissue fibrosis, possibly involving oxidative stress by inhibiting Akt signaling (Ying et al. 2017). Meanwhile, sonodynamic therapy inhibited fibrogenesis in rat cardiac fibroblasts by activating the AKT-GSK-3 $\beta$ pathway and blocking TGF- $\beta 1-S M A D 3$ signaling (Guo et al. 2016). In our investigation, ISO treatment decreased the protein level of phospho-GSK-3 $\beta$ at Ser9, accompanied by a decrease in phosphorylation of Akt at Ser473 as compared with control treatment. However, ghrelin treatment significantly reversed the downregulated $p$-Akt and $p$-GSK- $3 \beta$ levels in rat heart tissue. Several lines of evidence have also shown that ghrelin exerts its protective roles by activating the Akt-GSK-3 $\beta$ pathway in different types of organ damage (Lim et al. 2011, Chung et al. 2013).

Several articles reported ghrelin could activate GHS-R1a and then stimulate PI3K/Akt signaling pathway in several cells, including cardiomyocytes, endothelial cells and neurocytes (Baldanzi et al. 2002, LacerdaMiranda et al. 2012, Popelova et al. 2018). Our results also suggested that ghrelin activated PI3K/Akt signaling pathway demonstrated by the increased protein levels of $p$-Akt and $p$-GSK.

Our study suggests that ghrelin could attenuate ISO-induced myocardial fibrosis via the Akt-GSK-3 $\beta$ signaling pathway, which was mediated by GDF15. Therefore, ghrelin might have potential therapeutic value for mitigating excessive myocardial fibrosis, thereby improving cardiac function and outcomes in patients with HF.

\section{Conflict of Interest}

There is no conflict of interest.

\section{Acknowledgements}

This study was supported by Hangzhou Municipal Health Commission (No. 2015A15). 


\section{References}

ANAND IS, KEMPH T, RECTOR TS, TAPKEN H, ALLHOFF T, JANTZEN F, KUSKOWSKI M, COHN JN, DREXLER H, WOLLERT KC: Serial measurement of growth-differentiation factor-15 in heart failure: relation to disease severity and prognosis in the Valsartan Heart Failure Trial. Circulation 122: 1387-1395, 2010. https://doi.org/10.1161/CIRCULATIONAHA.109.928846

BALDANZI G, FILIGHEDDU N, CUTRUPI S, CATAPANO F, BONISSONI S, FUBINI A, MALAN D, BAJ G, GRANATA R, BROGLIO F, PAPOTTI M, SURICO N, BUSSOLINO F, ISGAARD J, DEGHENGHI R, SINIGAGLIA F, PRAT M, MUCCIOLI G, GHIGO E, GRAZIANI A: Ghrelin and des-acyl ghrelin inhibit cell death in cardiomyocytes and endothelial cells through ERK1/2 and PI 3-kinase/AKT. J Cell Biol 159: 1029-1037, 2002. https://doi.org/10.1083/jcb.200207165

CAMARGO-SILVA G, TURONES LC, DA CRUZ KR, GOMES KP, MENDONCA MM, NUNES A, DE JESUS IG, COLUGNATI DB, PANSANI AP, POBBE RLH, SANTOS R, FONTES MAP, GUATINOSIM S, DE CASTRO CH, IANZER D, FERREIRA RN, XAVIER CH: Ghrelin potentiates cardiac reactivity to stress by modulating sympathetic control and beta-adrenergic response. Life Sci 196: 84-92, 2018. https://doi.org/10.1016/j.lfs.2018.01.019

CHUNG H, LI E, KIM Y, KIM S, PARK S: Multiple signaling pathways mediate ghrelin-induced proliferation of hippocampal neural stem cells. J Endocrinol 218: 49-59, 2013. https://doi.org/10.1530/JOE-13-0045

CIESZKOWSKI J, WARZECHA Z, CERANOWICZ P, CERANOWICZ D, KUSNIERZ-CABALA B, PEDZIWIATR M, DEMBINSKI M, AMBROZY T, KACZMARZYK T, PIHUT M, WIECKIEWICZ M, OLSZANECKI R, DEMBINSKI A: Therapeutic effect of exogenous ghrelin in the healing of gingival ulcers is mediated by the release of endogenous growth hormone and insulin-like growth factor-1. J Physiol Pharmacol 68: 609-617, 2017.

EID RA, ALKHATEEB MA, ELEAWA S, AL-HASHEM FH, AL-SHRAIM M, EL-KOTT AF, ZAKI MSA, DALLAK MA, ALDERA H: Cardioprotective effect of ghrelin against myocardial infarction-induced left ventricular injury via inhibition of SOCS3 and activation of JAK2/ STAT3 signaling. Basic Res Cardiol 113: 13, 2018. https://doi.org/10.1007/s00395-018-0671-4

GONZALEZ A, SCHELBERT EB, DIEZ J, BUTLER J: Myocardial interstitial fibrosis in heart failure: biological and translational perspectives. J Am Coll Cardiol 71: 1696-1706, 2018. https://doi.org/10.1016/j.jacc.2018.02.021

GUO Y, DONG Z, SHI Y, WANG W, WANG L, SUN J, SUN X, TIAN Z, YAO J, LI Z, CHENG J, TIAN Y: Sonodynamic therapy inhibits fibrogenesis in rat cardiac fibroblasts induced by TGF- $\beta 1$. Cell Physiol Biochem 40: 579-588, 2016. https://doi.org/10.1159/000452571

HEGER J, SCHIEGNITZ E, VON WALDTHAUSEN D, ANWAR MM, PIPER HM, EULER G: Growth differentiation factor 15 acts anti-apoptotic and pro-hypertrophic in adult cardiomyocytes. J Cell Physiol 224: 120-126, 2010. https://doi.org/10.1002/jep.22102

KEMPF T, EDEN M, STRELAU J, NAGUIB M, WILLENBOCKEL C, TONGERS J, HEINEKE J, KOTLARZ D, XU J, MOLKENTIN JD, NIESSEN HW, DREXLER H, WOLLERT KC: The transforming growth factor-beta superfamily member growth-differentiation factor- 15 protects the heart from ischemia/reperfusion injury. Circ Res 98: 351-360, 2006. https://doi.org/10.1161/01.RES.0000202805.73038.48

KEMPF T, WOLLERT KC: Growth-differentiation factor-15 in heart failure. Heart Fail Clin 5: 537-547. 2009. https://doi.org/10.1016/j.hfc.2009.04.006

KEMPF T, ZARBOCK A, WIDERA C, BUTZ S, STADTMANN A, ROSSAINT J, BOLOMINI-VITTORI M, KORF-KLINGEBIEL M, NAPP LC, HANSEN B, KANWISCHER A, BAVENDIEK U, BEUTEL G, HAPKE M, SAUER MG, LAUDANNA C, HOGG N, VESTWEBER D, WOLLERT KC: GDF-15 is an inhibitor of leukocyte integrin activation required for survival after myocardial infarction in mice. Nat Med 17: 581-588, 2011. https://doi.org/10.1038/nm.2354

LACERDA-MIRANDA G, SOARES VM, VIERIA AK, LESSA JG, RODRIGUES-CUNHA AC, CORTEZ E, GARCIA-SOUZA EP, MOURA AS: Ghrelin signaling in heart remodeling of adult obese mice. Peptides 35 : 65-73, 2012. https://doi.org/10.1016/j.peptides.2012.02.025 
LAI CC, LIU CP, CHENG PW, LU PJ, HSIAO M, LU WH, SUN GC, LIOU JC, TSENG CJ: Paricalcitol attenuates cardiac fibrosis and expression of endothelial cell transition markers in isoproterenol-induced cardiomyopathic rats. Crit Care Med 44: e866-e874, 2016. https://doi.org/10.1097/CCM.0000000000001736

LEWIS FC, KUMAR SD, ELLISON-HUGHES GM: Non-invasive strategies for stimulating endogenous repair and regenerative mechanisms in the damaged heart. Pharmacol Res 127: 33-40, 2018. https://doi.org/10.1016/j.phrs.2017.08.016

LILLENESS BM, FRISHMAN WH: Ghrelin and the cardiovascular system. Cardiol Rev 24: 288-297, 2016. https://doi.org/10.1097/CRD.0000000000000113

LIM E, LEE S, LI E, KIM Y, PARK S: Ghrelin protects spinal cord motoneurons against chronic glutamate-induced excitotoxicity via ERK1/2 and phosphatidylinositol-3-kinase/Akt/glycogen synthase kinase-3 $\beta$ pathways. Exp Neurol 230: 114-122, 2011. https://doi.org/10.1016/j.expneurol.2011.04.003

LOK SI, WINKENS B, GOLDSCHMEDING R, VAN GEFFEN AJ, NOUS FM, VAN KUIK J, VAN DER WEIDE P, KLOPPING C, KIRKELS JH, LAPHOR JR, DOVENDANS PA, DE JONGE N, DE WEGER RA: Circulating growth differentiation factor-15 correlates with myocardial fibrosis in patients with non-ischaemic dilated cardiomyopathy and decreases rapidly after left ventricular assist device support. Eur J Heart Fail 14: 1249-1256, 2012. https://doi.org/10.1093/eurjhf/hfs120

LIN Y, MATSUMURA K, FUKUHARA M, KAGIYAMA S, FUJII K, IIDA M: Ghrelin acts at the nucleus of the solitary tract to decrease arterial pressure in rats. Hypertension 43: 977-982, 2004. https://doi.org/10.1161/01.hyp.0000122803.91559.55

MAO Y, TOKUDOME T, KISHIMOTO I, OTANI K, NISHIMURA H, YAMAGUCHI O, OTSU K, MIYAZATO M, KANGAWA K: Endogenous ghrelin attenuates pressure overload-induced cardiac hypertrophy via a cholinergic anti-inflammatory pathway. Hypertension 65: 1238-1244, 2015. https://doi.org/10.1161/HYPERTENSIONAHA.114.04864

MAO Y, ZHANG S, YU F, LI H, GUO C, FAN X: Ghrelin attenuates liver fibrosis through regulation of TGF- $\beta 1$ expression and autophagy. Int J Mol Sci 16: 21911-21930, 2015. https://doi.org/10.3390/ijms160921911

MOHAMED SS, AHMED LA, ATTIA WA, KHATTAB MM: Nicorandil enhances the efficacy of mesenchymal stem cell therapy in isoproterenol-induced heart failure in rats. Biochem Pharmacol 98: 403-411, 2015. https://doi.org/10.1016/j.bcp.2015.10.004

MORINE KJ, QIAO X, YORK S, NATOV PS, PARUCHURI V, ZHANG Y, ARONOVITZ MJ, KARAS RH, KAPUR NK: Bone morphogenetic protein 9 reduces cardiac fibrosis and improves cardiac function in heart failure. Circulation 138: 513-526, 2018. https://doi.org/10.1161/CIRCULATIONAHA.117.031635

NAGAYA N, MORIYA J, YASUMMURA Y, UEMATSU M, ONO F, SHIMIZU W, UENO K, KITAKAZE M, MIYATAKE K, KANGAWA K: Effects of ghrelin administration on left ventricular function, exercise capacity, and muscle wasting in patients with chronic heart failure. Circulation 110: 3674-3679, 2004. https://doi.org/10.1161/01.CIR.0000149746.62908.BB

NUAMNAICHATI N, SATO VH, MOONGKARNDI P, PARICHATIKANOND W, MANGMOOL S: Sustained $\beta$-AR stimulation induces synthesis and secretion of growth factors in cardiac myocytes that affect on cardiac fibroblast activation. Life Sci 193: 257-269, 2018. https://doi.org/10.1016/j.lfs.2017.10.034

PEI XM, YUNG BY, YIP SP, YING M, BENZIE IF, SIU PM: Desacyl ghrelin prevents doxorubicin-induced myocardial fibrosis and apoptosis via the GHSR-independent pathway. Am J Physiol Endocrinol Metab 306: E311-E323, 2014. https://doi.org/10.1152/ajpendo.00123.2013

PETER PS, BRADY JE, YAN L, CHEN W, ENGELHARDT S, WANG Y, SADOSHIMA J, VATNER SF, VATNER DE: Inhibition of p38 alpha MAPK rescues cardiomyopathy induced by overexpressed beta 2-adrenergic receptor, but not beta 1-adrenergic receptor. J Clin Invest 117: 1335-1343, 2007. https://doi.org/10.1172/JCI29576

POPELOVA A, KAKONOVÁ A, HRUBA L, KUNES J, MALETINSKA L, ŽELEZNA B: Potential neuroprotective and anti-apoptotic properties of a long-lasting stable analog of ghrelin: an in vitro study using SH-SY5Y cells. Physiol Res 67: 339-346, 2018. https://doi.org/10.33549/physiolres.933761

PRABBU SD, FRANGOGIANNIS NG: The biological basis for cardiac repair after myocardial infarction: from inflammation to fibrosis. Circ Res 119: 91-112, 2016. https://doi.org/10.1161/CIRCRESAHA.116.303577 
SANTHANAKRISHNAN R, CHONG JP, NG TP, LING LH, SIM D, LEONG KT, YEO PS, ONG HY, JAUFEERALLY F, WONG R, CHAI P, LOW AF, RICHARDS AM, LAM CS: Growth differentiation factor 15, ST2, high-sensitivity troponin $\mathrm{T}$, and N-terminal pro brain natriuretic peptide in heart failure with preserved vs. reduced ejection fraction. Eur J Heart Fail 14: 1338-1347, 2012. https://doi.org/10.1093/eurjhf/hfs130

SHAH AM, MANN DL: In search of new therapeutic targets and strategies for heart failure: recent advances in basic science. Lancet 378: 704-712, 2011. https://doi.org/10.1016/S0140-6736(11)60894-5

SHIH YC, CHEN CL, ZHANG Y, MELLOR RL, KANTER EM, FANG Y, WANG HC, HUNG CT, NONG JY, CHEN HJ, LEE TH, TSENG YS, CHEN CN, WU CC, LIN SL, YAMADA KA, NERBONNE JM, YANG KC: Endoplasmic reticulum protein TXNDC5 augments myocardial fibrosis by facilitating extracellular matrix protein folding and redox-sensitive cardiac fibroblast activation. Circ Res 122: 1052-1068, 2018. https://doi.org/10.1161/CIRCRESAHA.117.312130

SHIRAI M, JOE N, TSUCHIMOCHI H, SONOBE T, SCHWENKE DO: Ghrelin supresses sympathetic hyperexcitation in acute heart failure in male rats: assessing centrally and peripherally mediated pathways. Endocrinology 156: 3309-3316, 2015. https://doi.org/10.1210/EN.2015-1333

SOEKI T, KISHIMOTO I, SCHWENKE DO, TOKUDOME T, HORIO T, YOSHIDA M, HOSODA H, KANGAWA K: Ghrelin suppresses cardiac sympathetic activity and prevents early left ventricular remodeling in rats with myocardial infarction. Am J Physiol Heart Circ Physiol 294: H426-H432, 2008. https://doi.org/10.1152/ajpheart.00643.2007

SU SA, YANG D, WU Y, XIE Y, ZHU W, CAI Z, SHEN J, FU Z, WANG Y, JIA L, WANG Y, WANG JA, XIANG M: EphrinB2 regulates cardiac fibrosis through modulating the interaction of Stat3 and TGF- $\beta / \mathrm{Smad} 3$ signaling. Circ Res 121: 617-627, 2017. https://doi.org/10.1161/CIRCRESAHA.117.311045

SUN GX, DING R, LI M, GUO Y, FAN LP, YUE LS, LI LY, ZHAO M: Ghrelin attenuates renal fibrosis and inflammation of obstructive nephropathy. J Urol 193: 2107-2015, 2015. https://doi.org/10.1016/j.juro.2014.11.098

TRAVERS JG, KAMAL FA, VALIENTE-ALANDI I, NIEMAN ML, SARGENT MA, LORENZ JN, MOLKENTIN JD, BLAXALL BC: Pharmacological and activated fibroblast targeting of G $\beta \gamma$-GRK2 after myocardial ischemia attenuates heart failure progression. $\mathrm{J}$ Am Coll Cardiol 70: 958-971, 2017. https://doi.org/10.1016/j.jacc.2017.06.049

VERGARO G, PRDU'HOMME M, FAZAL L, MERVAL R, PASSINO C, EMDIN M, SAMUEL JL, COHEN SOLAL A, DELCAYRE C: Inhibition of galectin-3 pathway prevents isoproterenol-induced left ventricular dysfunction and fibrosis in mice. Hypertension 67: 606-612, 2016. https://doi.org/10.1161/HYPERTENSIONAHA.115.06161

VERJANS R, PETERS T, BEAUMONT FJ, VAN LEEUWEN R, VAN HERWAARDEN T, VERHESEN W, MUNTS C, BIJNEN M, HENKENS M, DIEZ J, DE WINDT LJ, VAN NIEUWENHOVEN FA, VAN BILSEN M, GOUMANS MJ, HEYMANS S, GONZALEZ A, SCHROEN B: MicroRNA-221/222 Family counteracts myocardial fibrosis in pressure overload-induced heart failure. Hypertension 71: 280-288, 2018. https://doi.org/10.1161/HYPERTENSIONAHA.117.10094

VIRDIS A, DURANTI E, COLUCCI R, IPPOLITO C, TIROTTA E, LORENZINI G, BERNARDINI N, BLANDIZZI C, TADDEI S: Ghrelin restores nitric oxide availability in resistance circulation of essential hypertensive patients: role of NAD(P)H oxidase. Eur Heart J 36: 3023-3030, 2015. https://doi.org/10.1093/eurheartj/ehv365

VIRDIS A, LERMAN LO, REGOLI F, GHIADONI L, LERMAN A, TADDER S: Human ghrelin: a gastric hormone with cardiovascular properties. Curr Pharm Des 22: 52-58, 2016. https://doi.org/10.2174/1381612822666151119144458

WANG L, CHEN Q, LI G, KE D: Ghrelin ameliorates impaired angiogenesis of ischemic myocardium through GHSR1a-mediated AMPK/eNOS signal pathway in diabetic rats. Peptides 73: 77-87, 2015. https://doi.org/10.1016/j.peptides.2015.09.004

WANG L, CHEN Q, KE D, LI G: Ghrelin inhibits atherosclerotic plaque angiogenesis and promotes plaque stability in a rabbit atherosclerotic model. Peptides 90: 17-26, 2017. https://doi.org/10.1016/j.peptides.2017.01.013 
WANG Q, SUI X, CHEN R, MA P, DING T, SUI D, YANG P: Anti-fibrotic actions of ghrelin by inhibition of the NADPH oxidase-ROS signaling pathway. Clin Exp Pharmacol Physiol 45: 885, 2018. https://doi.org/10.1111/1440-1681.12948

WANG S, SUN A, LI L, ZHAO G, JIA J, WANG K, GE J, ZOU Y: Up-regulation of BMP-2 antagonizes TGF- $\beta 1 /$ ROCK-enhanced cardiac fibrotic signalling through activation of Smurf1/Smad6 complex. J Cell Mol Med 16: 2301-2310, 2012. https://doi.org/10.1111/j.1582-4934.2012.01538.x

WOLLERT KC, KEMPF T: GDF-15 in heart failure: providing insight into end-organ dysfunction and its recovery? Eur J Heart Fail 14: 1191-1193, 2012. https://doi.org/10.1093/eurjhf/hfs 158

XU X, DING F, PANG J, GAO X, XU RK, HAO W, CAO JM, CHEN C: Chronic administration of hexarelin attenuates cardiac fibrosis in the spontaneously hypertensive rat. Am J Physiol Heart Circ Physiol 303: H703-H711, 2012. https://doi.org/10.1152/ajpheart.00257.2011

XU XY, NIE Y, WANG FF, BAI Y, LV ZZ, ZHANG YY, LI ZJ, GAO W: Growth differentiation factor (GDF)-15 blocks norepinephrine-induced myocardial hypertrophy via a novel pathway involving inhibition of epidermal growth factor receptor transactivation. J Biol Chem 289: 10084-10094, 2014. https://doi.org/10.1074/jbc.M113.516278

YANG C, LIU J, LIU K, DU B, SHI K, DING M, LI B, YANG P: Ghrelin suppresses cardiac fibrosis of postmyocardial infarction heart failure rats by adjusting the activin A-follistatin imbalance. Peptides 99: 27-35, 2018. https://doi.org/10.1016/j.peptides.2017.10.018

YIN Q, LU H, BAI Y, TIAN A, YANG Q, WU J, YANG C, FAN TP, ZHANG Y, ZHENG X, ZHENG X, LI Z: A metabolite of Danshen formulae attenuates cardiac fibrosis induced by isoprenaline, via a NOX2/ROS/p38 pathway. Br J Pharmacol 172: 5573-5585, 2015. https://doi.org/10.1111/bph.13133

YING C, LIU T, LING H, CHENG M, ZHOU X, WANG S, MAO Y, CHEN L, ZHANG R, LI W: Glucose variability aggravates cardiac fibrosis by altering AKT signalling path. Diab Vasc Dis Res 14: 327-335, 2017. https://doi.org/10.1177/1479164117698917

ZHANG W, CHANCEY AL, TZENG HP, ZHOU Z, LAVINE KJ, GAO F, SIVASUBRAMANIAN N, BARGER PM, MANN DL: The development of myocardial fibrosis in transgenic mice with targeted overexpression of tumor necrosis factor requires mast cell-fibroblast interactions. Circulation 124: 2106-2116, 2011. https://doi.org/10.1161/CIRCULATIONAHA.111.052399. 